ROYAL SOCIETY

\section{Kapitza and Rutherford}

DR P. Kapitza, director of the Institute for Physical Problems in Moscow, is to give this year's Royal Society Rutherford Memorial Lecture at the University of Alberta, Canada, on September 16. No Rutherford lecturer has previously been appointed from outside the Commonwealth since the lectures were founded in 1952 to be delivercd in overseas Commonwealth universities. Dr Kapitza became a Fellow of the Royal Society in 1929, and worked at the Cavendish and Mond Laboratories in Cambridge from 1921 to 1934.

The Rutherford Memorial Fund, which finances these lectures, contributes to the Royal Society's support of science in the Commonwealth, providing $£ 4,228$ in 1967-68. The fund was raised by subscription in 1950-51, and the income is used chiefly to award. scholarships to young graduate scientists so that they can pursue experimental research for three or more years in a Commonwealth country other than that in which they obtained their first degree. By the end of 1968, there had been twenty Rutherford Scholars, and a further award has just been made. Its holder is $\mathrm{Mr}$ P. J. Stiles of the University of Sydney, who will spend three years at the Department of Theoretical Chemistry in Cambridge investigating the optical behaviour of fluids in electromagnetic fields.

\section{PLANNING}

\section{More Delay on Levens Park}

THERE is, after all, to be a public inquiry into the route to be followed by the proposed Kendal link road from the M6 Motorway to the A6 through historic Levens Park, Westmorland. This means that there is still hope for the park's famous avenue of oaks, planted in the 17th century. The proposed route on which a Ministry of Transport order was made last year, has been criticized because it would result in at least five of the oaks at the northern end of the avenue having to be destroyed. Several alternative routes have been proposed since the link road was first discussed in 1964. The park's owner, Mr O. R. Bagot, has suggested that the road could bypass the end of the park by running through the grounds of a nearby convent and then cross over the gorge of the River Kent farther up river. This scheme has been rejected by Westmorland County Council and the ministry. There is, however, a more hopeful alternative route which has recently been considered by ministry engineers. It would run well clear of both the park and the convent, and provided that the bridge over the River Kent was well designed it need not intrude very much on the view north from the park. This route would be approved in prineiple by the planning committee of the council, if the minister, Mr Richard Marsh, himself approved it. Mr Marsh has, however, indicated that he still favours the original line through the park, saying that it would do less damage in broad landscaping and amenity terms than any of the other routes proposed, but ho has bowed to public opinion by ordering a public inquiry which should be some consolation to the "Save Iuevens Park" campaigners.

\section{Parliament in Britain}

Nessy

AFTER the investiture of the Prince of Wales and the resounding victory of the United States in the lunar stakes, all it needs to complete the summer is a sighting or two of the Loch Ness monster. In the House of Lords, Lord Hughes assured Lord Kilmany that any monsters that may chance to inhabit the loch will not be subjected to assault or damage by the submariners currently scurrying about on the loch's bed. The chief constable of the Inverness Constabulary has been assured that the submarine operations have no aggressive intent. (Oral answer, July 16.)

\section{Cleaning Public Buildings}

MPs were full of praise for the improvements to Trafalgar Square and Whitehall which have resulted from cleaning public buildings. The total cost of cleaning the dozen buildings that have been treated so far is

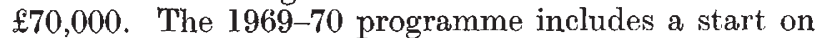
the Mall facade of Buckingham Palace, the Royal Naval College, the Tower of London and, as a gesture to Scotland and Wales, the Old Register House in Edinburgh and the Gwydyr House. Mr C. Loughlin, Parliamentary Secretary to the Ministry of Public Building and Works, added that the problem of reducing the numbers of pigeons and other birds seems completely intractable. (Oral answer, July 15.)

\section{Forestry}

Mr J. MAckIE told the Earl of Dalkeith that about 4 per cent of England and 8 per cent of Scotland is covered by productive forest, compared with 13 per cent in Europe as a whole. Mr W. Ross, Secretary of State for Scotland, denied that the Forestry Com. mission's planting programme was falling behind schedule. During the 18 months ending 31 March, 1969 , the commission planted 43,100 acres in Scotland and private landowners planted about 23,500 acres. Mr Ross, replying to the Earl of Dalkeith, said the total sum voted to the Forestry Commission since its establishment was $£ 234,088,000$ and the expectation value of the commission's plantations in production on March

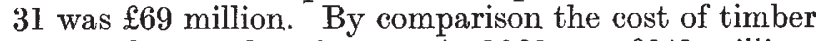
and timber product imports in 1968 was $£ 643$ million. (Written answers, July 15 and 16.)

\section{Open University}

MIss J. LeE for the Department of Education and Science said that enrolments for the Open University will begin in the autumn of 1970 and the university will start work in January 1971. Expenditure in 1968-69 was $£ 130,000$ and in $1969-70$ it is estimated that $£ 1 \cdot 7$ million will be spent. (Written answer, July 17.)

\section{Transport Museum}

Mrss J. LeE was in an unrepentant mood when she replicd to a barrage of questions critical of the decision to move 70 per cent of the Transport Museum, now housed at Clapham, to York. The remainder of the collection which related to London Transport would be reclaimed by London. Miss Lee said there was no room for expansion at Clapham and she denied that splitting the collection would result in converting a national transport museum into a provincial railway museum. York will also receive documents and records relating to transport for all of Britain apart from Scotland and London. Miss Lee maintained that York was the best place for the museum. (Oral answers, July 17.) 